\title{
Entrepreneurial Experience and the Innovativeness of Serial Entrepreneurs
}

\author{
Yancy Vaillant \\ Department of Strategy and Entrepreneurship. Toulouse Business School (TBS) \\ 1 Place Alphonse Jourdain, 31068 TOULOUSE Cedex 7, France \\ Email: y.vaillant@tbs-education.org \\ and \\ Departamento de Gestión Organizacional, Universidad de la Costa \\ Calle No 58, 55-66. Barranquilla, Colombia

\section{Esteban Lafuente} \\ Department of Management, Universitat Politècnica de Catalunya (Barcelona Tech) \\ EPSEB, Av. Gregorio Marañón, 44-50, E-08028 Barcelona, Spain \\ Tel: +34 93405 4476, Fax: +34 933348960 \\ Email: esteban.lafuente@upc.edu
}

\section{Working paper version. Please cite as:}

Vaillant, Y., Lafuente, E. (2018). Entrepreneurial experience and the innovativeness of serial entrepreneurs. Management Decision, in press, doi: 10.1108/MD-06-2017-0592

Acknowledgements: Esteban Lafuente acknowledges financial support from the Spanish Ministry of Economy, Industry and Competitiveness (Grant: ECO2017-86305-C4-2-R). 


\title{
Entrepreneurial Experience and the Innovativeness of Serial Entrepreneurs
}

\begin{abstract}
:
Purpose - This paper examines the effects of past entrepreneurial experience on the reported innovativeness of serial entrepreneurs' subsequent ventures. Building on insights from the generative entrepreneurial learning process and from cognition theories, we propose that regardless of the type of entrepreneurial experience, positive or negative, such experience enriches the cognitive schemas of serial entrepreneurs leading them to greater reported innovativeness. Knowing this will expand our knowledge of entrepreneurial career development.
\end{abstract}

Design/Methodology/approach - The proposed hypotheses are tested using Heckman regression models relating past entrepreneurial experience, current business ownership and reported innovativeness of current businesses on a unique sample drawn from a Catalan adult population survey. The data on the past entrepreneurial experience of the Catalan adult population were collected specifically for the purpose of this study.

Findings - Results reveal that practical experience is an essential prerequisite for entrepreneurial learning, and even negative entrepreneurial experience may induce generative entrepreneurial learning suitable for subsequent outperforming ventures for the psychologically strong who have managed to learn from their experience.

Implications - This paper offers insights on how the nature of the past entrepreneurial activity influences future venturing decisions. This study contributes to the academic debate on whether increased entrepreneurial experience and generative learning processes best explain serial entrepreneurial behaviors.

Originality/Value - The paper further explores the influence of previous entrepreneurial experience on current entrepreneurial activity by analyzing the relationship between serial entrepreneurship and reported innovativeness.

\section{INTRODUCTION}

Most research studying entrepreneurs assumes business creation is a one-off event. Yet, recent studies report that between a third and one half of business creators have had previous entrepreneurial experience (e.g., Sarasvathy et al., 2013; Ucbasaran et al., 2006; Ucbasaran et al., 2010). Thus, serial entrepreneurs, defined as individuals who sequentially pass from one business venture to another, are a representative segment of the entrepreneurially active population. 
MacMillan (1986) highlighted the centrality of serial entrepreneurs for understanding entrepreneurship and the entrepreneur. Notwithstanding the increased relevance of serial entrepreneurs for entrepreneurship researchers, there is still little analysis of the behavior of entrepreneurs in moving from initial to subsequent ventures. Most studies assume a homogeneous effect of previous entrepreneurial experience on future business creation (Schollhammer, 1991; Westhead and Wright, 1998). Yet, there is unclear evidence of the true benefits associated with entrepreneurial experience (Ucbasaran et al., 2009). The positive or negative outcome of previous entrepreneurial ventures may affect future business creation decisions in different ways. The literature is not clear whether entrepreneurs who have experienced business failure/success subsequently own firms that are less/more innovative (Ucbasaran et al., 2010).

According to theories of cognition and the generative learning coming from entrepreneurial experience (Baron, 1998; McGrath, 1999), serial entrepreneurs potentially run ever more successful businesses over time (Cope, 2005). However, a competing conjecture exists based on theories of affect, selective learning and hubris (Hayward et al., 2006; Shepherd, 2003), which asserts that those who succeed tend to fall into complacency traps and under-perform in their subsequent ventures. In contrast, those who fail, if they are able to fight off the 'grief' that may often prevent them from re-entry, mostly learn from and improve after failure (March, 1991; Shepherd, 2003).

The study presented in this paper looks into the role of past entrepreneurial experience on the reported innovativeness of serial entrepreneurs' subsequent ventures. In doing so we answer the call made by Cope (2005) for the study of serial entrepreneurs’ subsequent ventures through a generative entrepreneurial learning lens, as well as that of Ucbasaran et al. (2008) for more research on the performance of serial entrepreneurs that emphasizes the role of the entrepreneurs rather than the firm. Our research objective is to determine whether the outcome of past entrepreneurial experience (positive or negative) conditions the probability of embarking on subsequent ventures and whether these subsequent ventures outperform those of novice entrepreneurs in terms of reported innovativeness. 
The importance of this study stretches beyond a purely academic discussion and has implications for policy making within the area of business and economic development. For example, because entrepreneurs are prone to over-optimism (Hayward et al., 2006; Ucbasaran et al., 2006), some advocates and scholars call for tougher bankruptcy laws to discourage entrepreneurial 'over-engagement'. But, as Parker (2013) comments, this recommendation implicitly assumes that entrepreneurs would do no better in subsequent ventures were they to re-enter. Appropriate policy depends on the likeliness for serial entrepreneurs to improve. Thus, if serial entrepreneurs learn from their venturing experiences and/or acquire valuable knowledge from them, they may perform better, on average, in subsequent ventures (Parker, 2013). If subsequent ventures do build upon prior entrepreneurial experiences, calls for policy to encourage re-entries by entrepreneurs may be warranted, even if those entrepreneurs performed poorly in their previous ventures.

\section{THEORETICAL UNDERPINNING AND HYPOTHESES DEVELOPMENT}

Those habitual entrepreneurs who exit one venture before entering into a subsequent one are referred to as serial entrepreneurs (Wright et al., 1997). Serial entrepreneurs are relatively common. They represent a proportion of business owners that range from 51-63\% in the US (Schollhammer, 1991), to 34\% in Norway (Kolvereid and Bullvag, 1993), 49\% in Australia (Taylor, 1999), and 52\% in the UK (Ucbasaran et al., 2003) (as compiled by Uscasaran et al., 2006, p.1).

Several contributions by Westhead et al. (2005), Ucbasaran et al. (2006, 2008), and Sarasvathy et al. (2013) have improved our understanding of serial entrepreneurs in relation to contagion, comparative optimism and opportunity identification. Theoretical and empirical research has also analyzed the entry and re-entry decisions of serial entrepreneurs (Amaral et al., 2011; Stam et al., 2008) as well as their performance (Gompers et al., 2010; Toft-Kehler et al., 2014). But despite the growing mass of theoretical and empirical research on the subject, relatively little is known about how the outcome of serial entrepreneurs' prior venture is related to their performance in a subsequent venture. 
The few studies into the effects of past entrepreneurial experience on subsequent business performance offer varied results. Alsos and Kolvereid (1998) find no significant relation between entrepreneurial experience and the performance of serial entrepreneurs' subsequent ventures, while Ucbasaran et al. (2009) and Toft-Kehler et al. (2014) find contrasting and non-linear relationships between these two variables. Parker (2013), however, did conclude that venturing generates benefits which spill over from one venture into subsequent ones as a result of observing the entrepreneurial trajectories of serial entrepreneurs over a 25-year period. Thus, no clear relation between past entrepreneurial experience and subsequent entrepreneurial performance stands out from the existing literature.

For Sarasvathy et al. (2013), one reason for this lack of clarity in the results is the fact that failed firms, which are not always taken into consideration, are a way for serial entrepreneurs to learn what works and what does not work. Therefore, learning benefits occur as much through failed start-ups as through successful ones.

The way that an entrepreneur perceives new situations is linked to prior experiential learning and is greatly shaped by one’s evolving entrepreneurial history. Experience provides a framework that can be used to process information and therefore reduce the burden of information processing. Whereas novice entrepreneurs can become overwhelmed by information and how to use it, experienced individuals can concentrate on novel or unique information (Westhead et al., 2005).

According to Cope (2005) the interaction between the past and the future that stimulates intention and further action lies in the generative process of entrepreneurial learning (Wittrock, 1974). Generative learning is described as “the ability to extrapolate and bring forward one’s learning from critical events to new situations, incidents and experiences” (Cope, 2005, p. 386). Entrepreneurial learning is primarily experience based (Politis, 2005) and what an entrepreneur learns in one period is found to build upon what was learnt in previous periods to shape the 'stock' of knowledge and action that will guide future entrepreneurial behavior (Minniti and Bygrave, 2001). Generative learning is what enables serial entrepreneurs to "abstract and generalize across 
contexts, to recognize patterns and build relationships between different situations and events” (Cope, 2005, p. 386).

Because of the higher-order learning created through generative process, the outcomes and effectiveness of serial entrepreneurs can improve, and can do so across a broader range of new situations (Cope, 2005). The relatedness of events makes serial entrepreneurs better able to understand and deal with current challenges. This generative learning is equivalent to building a greater reference frame that helps serial entrepreneurs develop a cognitive schema that allows them to better understand and manage future entrepreneurial experiences (Huber, 1991, Cope, 2005).

Serial entrepreneurs are known to develop cognitive schemas that facilitate the encoding and selective access of valuable information, abstract representation and retrieval of relevant information (Baron, 1998; Sarasvathy et al., 2013). The cognitive schemas of serial entrepreneurs were found to be more clearly defined, richer in content, and more concerned with factors and conditions related to actually starting and running a new venture (Baron and Ensley, 2006).

Therefore, the generative learning process from past entrepreneurial experience may influence an individual's cognitive schemas in a way that may be important in the decision to reengage in a new venture and thus become a serial entrepreneur. Variations in experience may explain why past entrepreneurs differ with regard to entrepreneurial re-entry decisions, and why decisions of serial entrepreneurs that ultimately affect the outcomes of their ventures may also differ from those individuals lacking entrepreneurial experience. Serial entrepreneurs are found by Westhead et al. (2005) to place stronger importance on opportunity identification and exploitation capabilities. Entrepreneurial outcomes such as the level of innovativeness may therefore be shaped by past entrepreneurial experience. Politis (2005) theorized that this could be so because of the greater opportunity recognition abilities and increased capabilities to cope with the liabilities of newness that individuals with past entrepreneurial experience have gained from their experience.

Positive past entrepreneurial experiences have been found to be more conducive to further re-entry into self-employment than negative past experiences (Amaral et al., 2011; Stam et al., 
2008; Ucbasaran et al., 2003, 2006; Weasthead et al., 2005). However, there is an intense debate regarding the consequences of negative previous business outcomes. While some scholars view failure as a learning opportunity (McGrath, 1999), others have argued that it may be difficult to learn from business failure (Shepherd, 2003). Ucbasaran et al. (2010) suggest that both views have some validity. Nevertheless, research has found that when it comes to business opportunity identification, business failure may encourage learning without dampening motivation (Ucbasaran et al., 2009). Van de Velde et al. (1992) point out that failure can facilitate learning by pushing individuals to conduct a post-mortem to understand what led to the failure. This view is shared by Ellis and Davidi (2005) who find that failure represents an 'important database' for learning, encouraging affected past entrepreneurs to ask the 'why' questions in relation to failure. Failure has been described as the 'fuel that intensifies cognitive processes' (Ucbasaran et al., 2010). This way, failure might encourage entrepreneurs to be more realistic about their own skills and their expectations with regard to a subsequent venture(s), thus improving the cognitive schema of serial entrepreneurs (Ucbasaran et al., 2009). Notwithstanding the academic debate over the impact of failure on entrepreneurial activity, it is proposed that both positive and negative experiences contribute to the generative learning process from entrepreneurial experience (Minniti and Bygrave, 2001; Cope, 2005). Therefore, keeping with the generative process view of entrepreneurial learning that build the cognitive schemas of serial entrepreneurs it is hypothesized that:

H1: Regardless of the type of past entrepreneurial experience (positive or negative), the current entrepreneurial activity of individuals with past entrepreneurial experience is greater than that of those without such experience.

\subsection{Innovativeness}

As compared to novice entrepreneurs who are at their first venturing attempt, the cognitive schemas of serial entrepreneurs developed from the generative nature of entrepreneurial experiential 
learning are found to be richer and more concerned with factors and conditions related to successfully running a new venture (Baron and Ensley, 2006). This allows serial entrepreneurs to more effectively run and grow their ventures which may result in better business outcomes when measured in terms of reported innovativeness. In fact, Westhead et al. (2005) found that serial entrepreneurs were significantly more likely than novice entrepreneurs to apply new ways of managing and developing their team of collaborators as well as more likely to develop new quality control and R\&D methods. These process advances were found to be coupled with the relatively greater introduction of new products or new qualities to existing product (Westhead et al., 2005: 407-408).

Alsos and Kolvereid (1998) argue that although experience is multidimensional, the entrepreneurs with previous entrepreneurial experience will do better than those without such experience, and this it has been argued is so because of the richer entrepreneurial cognitive schemas demonstrated by serial entrepreneurs.

Ucbasaran et al. (2009) observe that most studies exploring the relationship between entrepreneurial experience and outcomes focus on whether or not the entrepreneur has experience and assume that experience will be associated with superior outcomes (e.g., Baron and Ensley, 2006; Westhead and Wright, 1998). According to Politis (2005) the entrepreneurial 'mind-set' developed by serial entrepreneurs "drives them to seek and pursue opportunities with discipline”, and can therefore be expected to "pursue only the very best opportunities" (Politis, 2005, p. 403).

Empirically, experiential learning has been found to exert a positive effect upon the development of different types of skills such as resource-acquisition and organizing that are critical for greater venturing capacity, and therefore better entrepreneurial outcomes. The generative process of entrepreneurial learning leads past entrepreneurship experience to increase survival rates by influencing expectations and strengthening the perception of preparedness (Headd, 2003).

Serial entrepreneurs are therefore found to be more successful than novice entrepreneurs in terms of choosing potentially more profitable new ventures (Baron and Ensley, 2006). The 
generative nature of entrepreneurial experience gives serial entrepreneurs cognitive abilities that are critical for opportunity recognition, evaluation and selection. When it comes to innovativeness, the generative process of entrepreneurial learning brings serial entrepreneurs to think in ways that help them keep their eyes firmly on what is feasible, while avoiding the potential trap of being swept away by what is merely 'new' or 'unique' (Cope, 2005; Baron and Ensley, 2006). According to Ucbasaran et al. (2009) serial entrepreneurs with their relatively more developed cognitive schemas may identify not only more opportunities but also better and more innovative opportunities. Serial entrepreneurs are able to 'connect the dots' between seemingly unrelated changes or events and detect meaningful patterns to a greater extent than inexperienced entrepreneurs (Baron and Ensley, 2006).

According to Ucbasaran et al. (2009) the nature of prior experience shapes the way in which current challenges are framed. Past entrepreneurial experience, whether perceived as positive or negative, may shape the outcome of subsequent businesses by influencing the cognitive processes needed for creativity and successful venturing (Ucbasaran et al., 2009; Ward, 2004).

For the most part, research shows that past positive experience has beneficial effects on the cognitive schemas of the entrepreneur, thus leading to better subsequent venturing (Gompers et al., 2010; Parker, 2013; Westhead et al., 2005). According to Hogarth and Karelaia (2012) the cognitive benefits of past positive experience, that we argue come from the generative process of entrepreneurial learning, allows serial entrepreneurs to better estimate how well they can do something; because they have done it, or something similar, several times before.

Parker (2013) finds that the amount of experience that actors have in a particular task domain, also called cultural embeddedness, has a substantial impact on the perception of innovation among entrepreneurs. Whereas entrepreneurs with long prior industry experience are found to be less likely to consider fresh organizational ideas in their startups (March, 1991), this relation is offset by the generative learning process of entrepreneurial experience (Ruef, 2002). Indeed, the past entrepreneurial experience of serial entrepreneurs, contrary to past industry-specific work 
experience, led to an increase in predictive likelihood of innovativeness among entrepreneurs (Ruef, 2002). Because experienced individuals can process new information more effectively than inexperienced individuals, it has been found that they are better inclined for creativity and innovativeness (Westhead et al., 2005). It is argued that the cognitive schema of the serial entrepreneur consciously draws from past entrepreneurial experience through generative learning, and this whether the experience involved conventional skill, tacit knowledge or prior attempts to innovate and deviate from convention.

Although a negative past entrepreneurial experience is generally undesirable, perceived failure can have positive consequences (Shepherd, 2003). A reason why failure offers benefits is because it is often easier to pinpoint why failure has occurred than to explain a success (McGrath, 1999). But there is a difference between failures with little cognitive or learning benefits (as described by Shepherd (2003) in his analysis of the emotional cost of failure) and 'Intelligent Failures’ (Sitkin, 1992). Intelligent failures are those in which expectations are not met but something useful for the future is learnt (McGrath, 1999). Further research reveals that entrepreneurs learn much through failure, not only about themselves and their ventures, but also about the nature of networks and relationships of venture management (Cope, 2011). These powerful generative learning outcomes are future-oriented, thus increasing the entrepreneur's level of entrepreneurial preparedness for further enterprising activities and ability to successfully innovate. Therefore, it is hypothesized that:

H2: Regardless of the type of past entrepreneurial experience (positive or negative), the reported innovativeness of businesses owned by serial entrepreneurs is greater than that of novice entrepreneurs.

\section{DATA, VARIABLES AND RESEARCH METHODS}

\subsection{Data}


Ucbasaran et al. (2009) observe that, contrary to an experimental setting, the evidence obtained from a representative sample of the adult population, including that of serial and novice entrepreneurs is more suitable for examining questions related to the nature and limits of previous entrepreneurial experience. The proposed model is therefore tested using a unique primary dataset about the past entrepreneurial experience of the Catalan adult population. The data were collected specifically for the purpose of this study by 'piggybacking' upon the Catalan Global Entrepreneurship Monitor's adult population survey for the year 2010. This was done in order to benefit from a rigorous and recognized source of randomly collected representative data offering a source of profile information on individuals and ventures. The survey was conducted by a leading professional market investigation and public opinion service firm selected and monitored directly by the International GEM Consortium. The sample was built based on a multiple stage sampling method using the Bellview Fusion computer-assisted telephone interview system. In the first stage, municipalities were randomly selected according to population quotas. In the second stage, telephone numbers corresponding to the different municipalities were randomly obtained from the annually updated 'España Office v5.2' database of fixed and mobile telephones. Finally, individuals aged between 18 and 65 inclusive were randomly selected by the aforementioned software.

Given the objective of the paper and the emphasis on the entrepreneur as the unit of analysis, specific questions dealing with the respondent's entrepreneurial experience were added to the structured questionnaire. Specifically, individuals were asked whether they were first-time entrepreneurs (novice) or repeat entrepreneurs (serial). Additionally, serial entrepreneurs were asked to appraise their previous entrepreneurial experience to determine whether it was perceived as a positive or negative experience. This specific data not only allows for the study of the impact of past entrepreneurial experience on current business creation decisions, but also permits the analysis of the effect on current business outcome (reported innovativeness) of previous entrepreneurial experience. 
The original database included 2000 individuals. In order to ensure the robustness of the results, the final dataset includes those observations for which a complete set of valid responses was obtained. The final stratified random sample comprises information for 1984 respondents from the adult population, of which 246 are current entrepreneurs (12.40\%) and 380 respondents (19.15\%) have previous entrepreneurial experience.

\subsection{Dependent variables}

\subsubsection{Business ownership}

As previously mentioned, the first analytical stage evaluates the impact of previous entrepreneurial experience on current entrepreneurial activity. To this end, the first dependent variable identifies whether the respondent is currently active as an entrepreneur (yes=1, no=0). From Table 1 we note that the final sample includes 246 current entrepreneurs. The sample of entrepreneurs is mainly comprised of men (64\%) and they are significantly older (on average: 46 years old) than non-entrepreneurially active individuals (on average: 44 years old).

\subsubsection{Reported innovativeness}

In the second stage, we evaluate the effect of past entrepreneurial experience on current levels of reported innovativeness. Prior studies suggest that key informants provide reliable information about the characteristics of their businesses, including valuations of innovativeness (Thornhill, 2006). Thus, this study keeps with the tradition of using self-reported statements to operationalize innovativeness (Ucbasaran et al., 2009). Respondents were asked along a three-point scale ( $1=$ low, $2=$ medium, $3=$ high) to provide their valuation to the following aspects of innovativeness: 1) the degree of newness of their product or the characteristics of their product, 2) the introduction of new production techniques or the modifications introduced to existing production systems through the use of cutting-edge technologies, and 3) the adoption of innovative strategic actions to compete in the market according to the number of competitors in the market. 
Despite being a self-reported measure, this multi-item innovativeness construct goes beyond a simple proxy capturing the optimistic attitude of entrepreneurs towards the innovativeness of their current business venture.

Factor analysis was used to assess the capacity of the analyzed variables to reflect an unobserved (latent) construct related to reported innovativeness. The result of the reliability test (Cronbach’s Alpha: 0.6760) corroborates that the reported innovativeness construct extracted from the factor analysis is internally consistent across items. The proportion of variance explained by the factor model is $55.41 \%$. Also, the result of the Kaiser-Meyer-Olkin (KMO) index of sampling adequacy is above the recommended cut-off point of $0.50(0.6130)$ confirming that the sample is factorable. These results corroborate that our approach to reported innovativeness is robust (Nunnally and Bernstein, 1994).

Similar to Ucbasaran et al. (2009), we employ a cross-cutting topic approach to reported innovativeness seeking to compute a variable that both captures the multidimensionality of innovativeness, and measures reported innovativeness in businesses operating in a variety of industry sectors with different technological regimes (i.e., low-tech and high-tech industries).

\subsection{Independent variables}

\subsubsection{Entrepreneurial experience}

Entrepreneurial experience represents a key source of knowledge. Individuals with this generative learning develop entrepreneurship-specific cognitive schemas that raise their probability to engaging in future business ventures. The increased entrepreneurial cognition of business owners with past-experience may translate in the pursuit of more innovative businesses. Respondents reported whether they have owned a business in the past (yes=1, no=0). Additionally, we explore the nature of the entrepreneurial experience. By definition novice entrepreneurs have no entrepreneurial experience. To evaluate the distinct effect of the type of entrepreneurial experience, serial entrepreneurs who have previously launched a business prior to their current venture provided 
information as to whether their prior entrepreneurial experience was positive or negative. We distinguish between serial entrepreneurs with positive entrepreneurial experience (yes=1, no=0) from those who had a negative experienced in the past (yes=1, no=0).

It should be mentioned that a negative entrepreneurial experienced described by the entrepreneur as failure is not necessarily an indication of financial unfeasibility. In fact, Headd (2003) found that about one third of firms were profitable at the time of closure. There is a need to differentiate between economic failure and emotional failure (Ucbasaran et al., 2010). Emotional failure is the termination of an initiative that has fallen short of its goals (McGrath, 1999). As with prior related studies, the failure to meet expectations is the negative entrepreneurial experience taken into account within this study (Sarasvathy et al., 2013).

Note that the repercussions from negative entrepreneurial experience, and consequently the social fear of entrepreneurial failure, is a cultural factor that is not constant across territories (Lafuente et al. 2007; Vaillant and Lafuente, 2007, Driga et al, 2009). In territories with high levels of social stigma towards failure, individuals are dissuaded from becoming entrepreneurs (Landier 2004). According to the European Commission (2003), entrepreneurs in Europe often face a social stigma of failure which augments the risks associated with engaging in entrepreneurial activities (Vaillant et al. 2011). Apart from the formal legal and financial consequences implied by bankruptcy and entrepreneurial failure, the informal social repercussions often act as important obstacles to entrepreneurship (Vaillant and Lafuente, 2007). The proportion of the adult population in Catalonia in 2010 who expressed the existence a social fear of entrepreneurial failure was of 42,04\% (Vaillant et al. 2011); practically the same as the average for the EU as a whole $(41,58 \%)$ (Coduras et al. 2011).

In the final sample, entrepreneurial experience is mostly positive among serial entrepreneurs. Out of the 380 serial entrepreneurs, 264 respondents report a positive entrepreneurial experience (i.e., 69\%) whereas 116 serial entrepreneurs (i.e., 31\%) had a negative entrepreneurial experience. This rate is similar to that reported in previous studies (Ucbasaran et al., 2010). 


\subsubsection{Control variables}

To isolate the differentiating effect that the type of entrepreneurial experience has on both the decision to create a business and reported innovativeness, certain control variables related to general human capital were included. Gender identifies whether the individual is a male (yes=1, no=0). Studies in entrepreneurship often report significant entrepreneurial activity between women and men (Brush, 1992; Driga et al., 2009). Age is expressed in years. Studies on the life span developmental approach in entrepreneurship support the idea that age matters for entrepreneurial success. The individual's education attainment is captured through a set of dichotomous variables distinguishing individuals with primary studies (yes $=1$, no=0), secondary studies (yes $=1$, no= $=0$ ), and post-secondary studies (yes $=1$, no=0).

In the second stage analysis, we control for the entrepreneur’s general human capital (gender, age and educational attainment) and for various organizational factors that might impact reported innovativeness. Business age, expressed in years, measures the vulnerability of the firm to market conditions due to liabilities of newness (Ucbasaran et al., 2013; Wiklund et al., 2010). To measure business age, the sampled entrepreneurs were asked to indicate the year in which their current business started its operations. In addition, we computed four industry dummy variables to rule out potential differences in reported innovativeness across industry sectors: extractive, manufacturing, business service sectors, and consumer service sectors. In all model specifications, the reference category was entrepreneurs engaged in extractive sectors.

--- Insert Tables 1 and 2 about here ---

\subsection{Method}

In line with the arguments that underpin this study (section 2), we argue that past entrepreneurial experience triggers both current entrepreneurial activity (H1) and the reported 
innovativeness of subsequent businesses created by serial entrepreneurs (H2). Thus, without modeling entrepreneurial (re)entry first, any model attempting to explain the effect of past entrepreneurial experience on current business' outcomes would yield biased results, regardless of whether the model controls for covariates linked to innovativeness (Wooldridge, 2002).

Given the characteristics of the proposed analysis, we consider the econometric problem of the relationship between entrepreneurial experience, entrepreneurial (re)entry and reported innovativeness a perfect candidate for a sample selection model (Heckman, 1979). The endogenous nature of entrepreneurial (re)entry implies that covariates explaining this decision are likely correlated to the error term of any model used to assess business innovativeness (Heckman and Robb, 1985). Additionally, the reported innovativeness level of average current businesses that were created by serial entrepreneurs may originate in factors other than those strictly related to the decision of becoming an entrepreneur, such as industry-related factors (Greene, 2003).

To address potential sample selection problems, we use the Heckman two-step procedure (Heckman, 1979). The Heckman two-step model represents a solution for the omitted variables bias (Heckman, 1979), and it allows to obtain consistent estimates for the effect of previous entrepreneurial experience on the reported innovativeness of current businesses.

The Heckman two-step model involves two equations. In the first step (selection equation), the probability of entrepreneurship is estimated on the full sample through the probit model. In this study, the full probit model that estimates the effect of past entrepreneurial experience on current business ownership has the following form:

$$
\begin{aligned}
\text { Entrepreneurship }_{i} & =\beta_{0}+\beta_{1} \text { Past positive entrepreneurial experience } \\
& +\beta_{2} \text { Past negative entrepreneurial experience }{ }_{i}+\beta_{3} \text { Controls }_{i}+\varepsilon_{i}
\end{aligned}
$$

In equation (1) $\beta_{j}$ is the vector of coefficients and $\varepsilon_{i}$ is the normally distributed error term estimated for the sample observations (i). We expect that $\beta_{1}>0, \beta_{2}>0$ and $\beta_{1}=\beta_{2}$; that is, ceteris 
paribus, past entrepreneurial experience positively impacts current business ownership decisions, irrespective of the type of past entrepreneurial experience (H1).

The main purpose of this first step is to compute the correction factor of selection bias for the entire sample, called the inverse of the Mills ratio $(\lambda)$. The selection bias term $\left(\lambda_{i}\right)$ depends on the known parameters from the probit model and is estimated as $\phi\left(\beta X_{i}\right) / \Phi\left(\beta X_{i}\right)$ for entrepreneurs, and as $-\phi\left(\beta X_{i}\right) / 1-\Phi\left(\beta X_{i}\right)$ for the non-treated sub-sample (non-entrepreneurs), where $\phi$ and $\Phi$ denote the density function and the cumulative distribution function of the standard normal distribution, respectively (Heckman 1979). The inverse of the Mills ratio is strictly linked to the presence of self-selection bias, and a statistically significant coefficient for this term would indicate that the decision to create a business is not random.

Note that coefficients estimated by discrete choice models only indicate the direction of the effect of the analyzed variable on the dependent variable. For interpretation purposes, the magnitude of the key independent variables is determined by the average marginal effect (AME). The AME is the average change in the probability of the response variable as a result of a change in an independent variable across the sampled observations. Through this approach we can estimate marginal effects for each observation, thus the resulting AME not only captures individual-specific characteristics, but also gives more realistic estimation results (Greene, 2005). For each independent variable $(X)$ the AME is estimated as $A M E_{X}=\frac{1}{N} \sum_{i=1}^{N}\left\{F\left(\beta X \mid X_{i}=1\right)-F\left(\beta X \mid X_{i}=0\right)\right\}$.

The second step of the Heckman model estimates the outcome equation (innovativeness model) with the inverse of the Mills ratio as an explanatory variable as follows:

$$
\begin{aligned}
\text { Innovativeness }_{i} & =\delta_{0}+\delta_{1} \text { Past positive entrepreneurial experience } \\
& +\delta_{2} \text { Past negative entrepreneurial experience }{ }_{i}+\delta_{3} \text { Controls }_{i}+\delta_{4} \lambda_{i}+v_{i}
\end{aligned}
$$


In equation (2) coefficients $\left(\delta_{j}\right)$ are estimated via OLS and the model is performed solely on the sample of current business owners. The term $v_{i}$ is the normally distributed error term. In this case, we expect that $\delta_{1}>0, \delta_{2}>0$ and $\delta_{1}=\delta_{2}$; that is, ceteris paribus, the reported innovativeness of businesses owned by serial entrepreneurs is greater than that of novice entrepreneurs, regardless of the type of past entrepreneurial experience (H2).

\section{EMPIRICAL RESULTS}

The Heckman regression models relating past entrepreneurial experience, current business ownership and reported innovativeness of current businesses are depicted in Table 3. To address the threat of collinearity, we computed the variance inflation factor (VIF) to test if coefficients are amplified due to correlations across the explanatory variables. Table 3 reports the average VIF value for each regression. The results for the diagnostic test indicate that for all the independent variables the variance inflation factor is below the commonly used cut-off threshold of ten, confirming that model specifications do not suffer from collinearity problems (Greene, 2003).

The first model specification in Table 3 examines the role of previous entrepreneurial experience on future entrepreneurship engagement and reported innovativeness. Model specification 2 distinguishes serial entrepreneurs with past positive entrepreneurial experience from those with past negative entrepreneurial experience.

Concerning the probit model estimating the engagement in entrepreneurship, results show that past entrepreneurial experience has a significantly positive influence on current entrepreneurial activity. More concretely, results of specification 1 in Table 3 show that the probability to start a new business significantly increases by 3.08 percentage points $(Z$-value $=1.72$ and $p$-value $=0.085$ ) for individuals with previous entrepreneurial experience, compared to the probability of novice entrepreneurs who do not have entrepreneurial experience. The result is consistent with previous literature that equate this result as an indication that individuals gain specific entrepreneurial 
knowledge as a result of their prior start-up experience (Ucbasaran et al., 2003, Politis, 2005), increasing their probability to become serial entrepreneurs (Wright et al., 1997). Thus we confirm that previous entrepreneurial experience increases the probability of future start-ups.

--- Insert Table 3 about here ---

To correctly test whether the type of prior entrepreneurial experience impacts the probability to become an entrepreneur, we split the previous entrepreneurial experience into its two components (positive and negative). For interpretation purposes, the group of individuals with no entrepreneurial experience is the reference category. The results in specification 2 indicate that past positive experience strongly influences future entrepreneurship. More concretely, individuals with a positive past entrepreneurial experience are 4.43 percentage points $(\mathrm{Z}$-value $=2.21$ and $p$-value $=$ 0.027) more likely to engage in a new entrepreneurial venture, compared to the probability of individuals with no entrepreneurial experience. This suggests that individuals with positive past entrepreneurial experience have developed specific conditions that favor future entrepreneurial activities.

This result does not hold for the variable linked to past negative entrepreneurial experience. Individuals who have had a negative past entrepreneurial experience are not found to have any significantly greater probability to start a new business, compared to individuals who lack entrepreneurial experience. To further corroborate this result, we compared the two coefficients linked to past entrepreneurial experience. The result of the chi-square test reveals that the coefficient linked to past positive entrepreneurial experience is significantly higher than the parameter of previous negative entrepreneurial experience $($ Wald chi-square $=1.89$ and $p$-value $=$ 0.07). These findings therefore do not support hypothesis $\mathbf{H 1}$ and would tend to suggest that, as Shepherd (2003) proposed, the (de)motivational consequences of entrepreneurial failure over the business re-entry decision neutralize the potential cognitive benefits of such past experience. Apart 
from the potential liabilities resulting from entrepreneurial failure, such an event has a large impact on the local stigmatization of the entrepreneur and entrepreneurship, as well as on the individual entrepreneur's view of themselves following failure. Shepherd (2003) suggests that entrepreneurial failure can be a traumatic event that generates negative emotions which can interfere with learning.

Concerning the outcome model that scrutinizes the effect of past entrepreneurial experience on the current business' innovativeness, results indicate the advantage of serial entrepreneurs over first-time novice entrepreneurs in terms of the self-reported innovativeness of their current ventures. Serial entrepreneurs report significantly greater levels of innovativeness when compared to novice entrepreneurs. Similar results are found even when the nature of the past entrepreneurial experience is taken into account. Therefore, we find support for hypothesis H2. The positive or negative nature of a serial entrepreneur's past experience drive innovative actions by current entrepreneurs, thus leading them to demonstrate significantly greater levels of reported innovativeness compared to novice entrepreneurs. Because reported innovativeness is a multi-item construct extracted from factor analysis, two considerations are in order. First, values for the reported innovativeness variable are standardized factor scores so; therefore, regression coefficients for the outcome equation cannot be interpreted in a direct or conventional way. Second, it is unlikely that the results for the coefficients linked to past positive and negative entrepreneurial experience are a simple capture of optimistic attitude towards the innovativeness of the current business venture. Additionally, the comparison of the coefficients linked to past positive and negative entrepreneurial experience indicates that both parameters are not significantly different (Wald chi-square value = 0.03 and $p$-value $=0.87$ ), thus they have the same influence on reported innovativeness.

We can conclude that contrary to the re-entry decision for individuals with past entrepreneurial experience, where prior experience led only those with positive past experience towards significantly greater business (re)entry levels, the cognitive benefits of the generative 
learning process of entrepreneurial experience on the levels of reported innovativeness in subsequent venturing is similar irrespective of the nature of this past experience ${ }^{1}$.

We performed additional checks to further validate the robustness of our results. More concretely, we estimated the model relating past entrepreneurial experience and reported innovativeness (equation (2)) via standard OLS method. Results are presented in Table A3 of the Appendix. From the results, we note that the coefficients do not qualitatively vary with respect to those obtained from the Heckman model. The coefficients for the variables linked to past entrepreneurial experience (positive and negative entrepreneurial experience) are positive and significant. Once more, the coefficient for past positive entrepreneurial experience is not significantly different from that estimated for past negative entrepreneurial experience (F-value = 0.05 and $p$-value $=0.85$.

\section{DISCUSSION, IMPLICATIONS AND CONCLUDING REMARKS}

The study presented in this paper looks into whether the outcome of past entrepreneurial experience (positive or negative) conditions the probability to embark on subsequent ventures, and whether these new ventures make a greater contribution in terms of reported innovativeness. A model hypothesizing that past entrepreneurial experience, whether positive or negative, will significantly lead to greater entrepreneurial re-entry levels and subsequent reports of business innovativeness was devised from a generative view of entrepreneurial learning leading to entrepreneurship specific cognitive schemas that favor serial over novice entrepreneurs. Our theoretical approach offers a compelling vision of how serial entrepreneurs capitalize accumulated knowledge resulting from the generative learning from their past entrepreneurial experience.

\footnotetext{
${ }^{1}$ Further analysis not reported within this paper show that whereas innovativeness is substantiated by the cognitive benefits of past entrepreneurial experience, employment generation requires much more business specific accumulated knowledge through market specific experience to stimulate greater outcome. Serial entrepreneurs where not found to significantly generate more jobs than novice entrepreneurs.
} 
Results indicate that individuals with past entrepreneurial experience were significantly more likely than those without such experience to currently be involved in a business venture. But this only holds for individuals describing their past entrepreneurial experience as a positive one. Although past entrepreneurial experience contributes to the development of a specific cognitive schema that helps favor future entrepreneurial activities, these findings suggest that the possible liabilities and (de)motivational consequences of entrepreneurial failure over the business re-entry decision neutralize the potential cognitive benefits of such past experience.

Additionally, and irrespective of the nature of the past entrepreneurial experience, it was found that if individuals with past entrepreneurial experience repeated as entrepreneurs their subsequent ventures reported significantly greater levels of innovativeness when compared to novice entrepreneurs. It therefore would appear that the entrepreneurs who managed to overcome their past failure and re-enter into entrepreneurial venturing are likely to be the psychologically strong, and are the ones who seem to have gained generative knowledge from the failure experience. They are the ones who are thus more likely to declare innovativeness, in the same manner as those who have had a positive past entrepreneurial experience. Failure for serial entrepreneurs can be seen as a hurdle where those who overcome it are likely to be the psychologically strong who have managed to learn from their experience.

Therefore, entrepreneurs do appear to learn from experience by carrying-over the cognitive benefits of entrepreneurial experience to their levels of self-declared innovativeness in subsequent venturing, regardless of whether this experience was positive or negative. Entrepreneurs with past entrepreneurial experience, be it positive or negative in nature, have the potential to become successful and innovative future serial entrepreneurs (Westhead et al. 2005). In an economic context where innovativeness is increasingly the basis of competitiveness, policy encouraging serial entrepreneurs and entrepreneurial re-entry is called for.

This paper offers insights on how the nature of the past entrepreneurial activity influences future venturing decisions. This study contributes to the academic debate on whether increased 
entrepreneurial experience and generative learning processes best explain serial entrepreneurial behaviors. The accumulation of entrepreneurial specific cognition is demonstrated to be important for the inclination towards becoming a serial entrepreneur, but it might get overshadowed by the loss of entrepreneurial ambition showed by serial entrepreneurs with negative prior experience. Nevertheless, past entrepreneurial experiences, even when perceived as failures, offer opportunities for learning. This was found to particularly impact the levels of innovativeness that serial entrepreneurs report within their subsequent ventures.

Following our findings, past experience, regardless of its outcome, generates a learning process and thus matters in the decision to become a serial entrepreneur. Policy makers could accelerate this process by pairing individuals with past experience and newcomers who do not have past experience. Although generative experiential learning is mostly an individual process (Wittrock, 1974), experiments testing its transferability across socially tight communities have given positive results (Engle, 2006). There seems to be social learning benefits for individuals in close contact with counterparts having a rich experiential learning attainments (Moon, 2004; Silberman, 2007). By encouraging entrepreneurial experience-based heterogeneity within teams of business venturers, not only will the novice members potentially benefit from the experience and generative knowledge of their serial partners, but serial entrepreneurs having faced negative past entrepreneurial experiences may benefit from the drive, confidence and ambition of novice entrepreneurs; making them more likely to re-enter into entrepreneurship.

Practical experience is an essential prerequisite for entrepreneurial learning. For practitioners, the results of the study imply that it is important to capitalize the learning benefits of past experience. Entrepreneurs with a negative past experience should acknowledge that business failure does not equate to individual failure. For example, in a context of economic downturn business failures are not only caused by entrepreneurs' mistakes, but mostly by exogenous factors that indiscriminately affect business performance. 
A series of limitations to the present research must, however, be mentioned that, in turn, represent avenues for future research. Data collected regarding to the nature of serial entrepreneurs' prior ventures are perceptual and retrospective in nature. Baron and Ensley (2006) comment that memory is subject to distortion and changes over time. As a result, the presented findings should be read with caution. What may have been initially perceived as an entrepreneurial failure may be given a less harsh appreciation as the serial entrepreneur recognizes the cognitive benefits of such a prior experience on a current venture. The same can hold for the emotional consequences of past entrepreneurial experience which might dilute as time passes. Controls were included into our model to try to detect and counter such limitations. Nevertheless, resulting distortion may not be completely eliminated. Likewise, as a result of the adoption of a binary variable to capture entrepreneurial experience, the possible non-linear relationship between past experience and current performance, as reported by some authors in the literature (Ucbasaran et al., 2009 and Toft-Kehler et al., 2014), could not be tested in this study.

Similarly, entrepreneurial experience in the study was not qualified nor quantified so as to get greater precision on the amount and type of accumulated experience beyond the perceived positive or negative nature of this past experience. Further research could detail experience measures based on the number of years, number of prior businesses, or more business-specific features such as industry, scope and scale. Only specifically designed future research can completely eliminate these limitations and build upon the contributions made from present findings.

As for the independent variable, there is a multiplicity of business outcomes that can be used beyond self-reported innovativeness. The cognitive benefits of past entrepreneurial experience may depend on the business outcome analyzed. Future research should therefore introduce more outcome variables into the analysis (see, e.g., Toft-Kehler et al., 2014). Furthermore, as in the study by Baron and Ensley (2006), we should note that current entrepreneurs in this study headed firms that had existed for several years, which implies that they have achieved at least some modest 
success. Finally, the geographical specificity of the study and the cross-sectional nature of its dataset call for obvious caution when interpreting and generalizing its findings.

\section{REFERENCES}

Alsos, G.A. and Kolvereid, L. (1998), “The business gestation process of novice, serial, and parallel business founders”, Entrepreneurship, Theory and Practice, Vol. 22 No. 4, pp. 101-114.

Amaral, M., Baptista, R. and Lima, F. (2011), "Serial entrepreneurship: impact of human capital on time to re-entry”, Small Business Economics, Vol. 37, pp. 1-21.

Baron, R. (1998), “Cognitive mechanisms in entrepreneurship: why and when entrepreneurs think differently than other people”, Journal of Business Venturing, Vol. 13, pp. 275-294.

Baron, R. and Ensley, M. (2006), “Opportunity Recognition as the Detection of Meaningful Patterns: Evidence from Comparisons of Novice and Experienced Entrepreneurs”, Management Science, Vol. 52 No. 9, pp. 1331-1344.

Brush, C.G. (1992), “Research on women business owners: Past trends, a new perspective and future directions”, Entrepreneurship: Theory and Practice, Vol. 16 No. 4, pp. 5-31.

Coduras, A., Sánchez, M. C., Díaz, J. C., Vaillant, Y., \& Lafuente, E. (2011), Global Entrepreneurship Monitor. Informe Ejecutivo GEM España 2011, Fundación Xavier de Salas, Trujillo: Spain.

Cope, J. (2005), “Towards a dynamic learning perspective of entrepreneurship”, Entrepreneurship Theory and Practice, Vol. 29 No. 4, pp. 373-397.

Cope, J. (2011), “Entrepreneurial learning from failure: An interpretative phenomenological analysis”, Journal of Business Venturing, Vol. 26 No. 6, pp. 604-623.

Driga, O., Lafuente, E. and Vaillant, Y. (2009), "Reasons for the relatively lower entrepreneurial activity levels of rural women in Spain”, Sociologia Ruralis, Vol. 49 No. 1, pp. 70-96.

Ellis, S. and Davidi, I. (2005), “After-event reviews: drawing lessons from successful and failed experience”, Journal of Applied Psychology, Vol. 90 No. 5, pp. 857-871. 
Engle, R. (2006), “Framing Interactions to Foster Generative Learning: A Situative Explanation of Transfer in a Community of Learners Classroom”. Journal of the Learning Sciences, Vol. 15 No. 4, pp. 451-498.

European Commission (2003), Green Paper: Entrepreneurship in Europe. Communication from the Commission to the Council, the European Parliament, the European Economic and Social Committee and the Committee of the Regions, COM (03) 27. European Commission, Brussels.

Gompers, P., Kovner, A., Lerner, J. and Scharfsteina, D. (2010), “Performance persistence in entrepreneurship”, Journal of Financial Economics, Vol. 96, pp. 18-32.

Greene, W. (2003), Econometric Analysis, fifth edition, Prentice Hall, New Jersey.

Greene, W. (2005), “Reconsidering heterogeneity in panel data estimators of the stochastic frontier model”, Journal of Econometrics, Vol. 126 No. 2, pp. 269-303.

Hayward, M., Shepherd, D. and Griffin, D. (2006), “A hubris theory of entrepreneurship”, Management Science, Vol. 52 No. 2, pp. 160-172.

Headd, B. (2003), “Redefining business success: Distinguishing between closure and failure”, Small Business Economics, Vol. 21, pp. 51-62.

Heckman, J.J. (1979), “Sample Selection Bias as a Specification Error”, Econometrica, Vol. 47 No. 1, pp. 153-161.

Heckman, J.J. and Robb, R. (1985), “Alternative Methods for Evaluating the Impact of Interventions: An Overview”, Journal of Econometrics, Vol. 30, pp. 239-267.

Hogarth, R. and Karelaia, N. (2012), "Entrepreneurial Success and Failure: Confidence and Fallible Judgment”, Organization Science, Vol. 23 No. 6, pp. 1733-1747.

Huber, G. (1991), “Organizational Learning: The contributing process and the literatures”, Organization Science, Vol. 2 No. 1, pp. 88-115.

Kolvereid, L. and Bullvag, E. (1993), “Novices versus experienced business founders - an exploratory investigation”, in Birley, S. and MacMillan, I.C. (Eds.), Entrepreneurship Research: Global Perspectives, pp. 275-285. 
Lafuente, E., Y. Vaillant, and J. Rialp. (2007), “Regional differences in the influence of RoleModels: Comparing the Entrepreneurial Process of Rural Catalonia”, Regional Studies, Vol. 41 No. 6, pp. $779-795$.

Landier, A. (2004), "Entrepreneurship and the stigma of failure”, paper presented at the MIT Finance, Development and Macro Workshops, http://ssrn.com/abstract=850446

MacMillan, I.C. (1986), “Executive forum: To really learn about entrepreneurship, let’s study habitual entrepreneurs”, Journal of Business Venturing, Vol. 1, pp. 211-243.

March, J.G. (1991), “Exploration and exploitation in organizational learning”, Organization Science, Vol. 2 No. 1, pp. 71-87.

McGrath, R.G. (1999), “Falling forward: real options reasoning and entrepreneurial failure”, Academy of Management Review, Vol. 24, pp. 13-30.

Minniti, M. and Bygrave, W. (2001), “A dynamic model of entrepreneurial learning”, Entrepreneurship Theory and Practice, Vol. 25 No. 3, pp. 5-16.

Moon, J. (2004), A Handbook of Reflective and Experiential Learning: Theory and Practice. RoutledgeFalmer, New-York, USA.

Nunnally, J.C. and Bernstein, I.H. (1994), Psychometric Theory, third edition, McGraw-Hill, NewYork, USA.

Parker, S.C. (2013), “Do serial entrepreneurs run successively better-performing businesses?”, Journal of Business Venturing, Vol. 28 No. 5, pp. 652-666.

Politis, D. (2005), “The process of entrepreneurial learning: a conceptual framework”, Entrepreneurship Theory and Practice, Vol. 29 No. 4, pp. 399-424.

Ruef, M. (2002), “Strong ties, weak ties and islands: structural and cultural predictors of organizational innovation”, Industrial and Corporate Change, Vol. 11 No. 3, pp. 427-449.

Sarasvathy, S., Menon, A. and Kuechle, G. (2013), “Failing firms and successful entrepreneurs: serial entrepreneurship as a temporal portfolio”, Small Business Economics, Vol. 40, pp. 417434. 
Schollhammer, H. (1991), “Incidences and determinants of multiple entrepreneurship”, in Churchill, N.C., Bygrave, W.D., Covin, J., Sexton, D., Slevin, D., Vesper, K., and Wetzel, W. (Eds.), Frontiers of Entrepreneurship Research, Babson College, Wellesley.

Shepherd, D.A. (2003), "Learning from business failure: propositions of grief recovery for the selfemployed”, Academy of Management Review, Vol. 28, pp. 318-329.

Silberman, M. (2007), The Handbook of Experiential Learning. John Wiley \& Sons. CA., USA.

Sitkin, S.B. (1992), “Learning through failure: The strategy of small losses”, Research in Organizational Behavior, Vol. 14, pp. 231-266.

Stam, E., Audretsch, D. and Meijaard, J. (2008), “Renascent entrepreneurship”, Journal of Evolutionary Economics, Vol. 18 No. 3-4, pp. 493-507.

Taylor, M. (1999), “The small firm as a temporary coalition”, Entrepreneurship \& Regional Development, Vol. 11, pp. 1-19.

Thornhill, S. (2006), “Knowledge, innovation and SME performance: contrasts between high- and low-technology regimes”, Journal of Business Venturing, Vol. 21, pp. 687-703.

Toft-Kehler, R., Wennberg, K. and Kim P. (2014), “Practice makes perfect: Entrepreneurialexperience curves and venture performance”, Journal of Business Venturing, Vol. 29 No. 4, pp. 453-470.

Ucbasaran, D., Wright, M. and Westhead, P. (2003), “A Longitudinal Study of Habitual Entrepreneurs: Starters and Acquirers”, Entrepreneurship and Regional Development, Vol. 15 No. 3, pp. 207-228.

Ucbasaran, D., Westhead, P. and Wright, M. (2006), Habitual Entrepreneurs, Edward Elgar Publishing, Aldershot, UK.

Ucbasaran, D., Westhead, P. and Wright, M. (2008), “Opportunity identification and pursuit: does an entrepreneur’s human capital matter?”, Small Business Economics, Vol. 2, pp. 153-173. 
Ucbasaran, D., Westhead, P. and Wright, M. (2009), “The extent and nature of opportunity identification by experienced entrepreneurs”, Journal of Business Venturing, Vol. 24 No. 2, pp. 99-115.

Ucbasaran, D., Westhead, P., Wright, M. and Flores, M. (2010), “The nature of entrepreneurial experience, business failure, and comparative optimism”, Journal of Business Venturing, Vol. 25 No. 6, pp. 541-555.

Ucbasaran, D., Shepherd, D.A., Lockett, A. and Lyon, S.J. (2013), "Life after Business Failure: The Process and Consequences of Business Failure for Entrepreneurs”, Journal of Management, Vol. 39 No. 1, pp. 163-202.

Vaillant, Y., and Lafuente, E. (2007), “Do different institutional frameworks condition the influence of local fear of failure and entrepreneurial examples over entrepreneurial activity?”, Entrepreneurship and Regional Development, Vol. 19 No. 4, pp. 313-337.

Vaillant, Y., Guallarte, C., Lafuente, E., Fíguls, M., \& Mancilla, C. (2011), Global Entrepreneurship Monitor: GEM Catalunya Informe Executiu 2010. IERMB, Barcelona: Spain.

Van de Velde, F., Hooykaas, C. and van der Pligt, J. (1992), “Risk perception and behavior: pessimism, realism and optimism about AIDS-related health behavior”, Psychology and Health, Vol. 6, pp. 23-38.

Ward, T.B. (2004), “Cognition, creativity and entrepreneurship”, Journal of Business Venturing, Vol. 19 No. 2, pp. 173-188.

Westhead, P. and Wright, M. (1998), “Novice, portfolio and serial founders: are they different?”, Journal of Business Venturing, Vol. 13 No. 3, pp. 173-204.

Westhead, P., Ucbasaran, D. and Wright, M. (2005), “Decisions, Actions, and Performance: Do Novice, Serial, and Portfolio Entrepreneurs Differ?”, Journal of Small Business Management, Vol. 43 No. 4, pp. 393-417.

Wiklund, J., Baker, T. and Shepherd, D. (2010), “The age-effect of financial indicators as buffers against the liabilities of newness”, Journal of Business Venturing, Vol. 25 No. 4, pp. 423-437. 
Wittrock, M.C. (1974), “Learning as a generative process”. Educational Psychologist, Vol. 11 No. 2, pp. 87-95.

Wooldridge, J. (2002), Econometric Analysis of Cross Section and Panel Data, The MIT Press, Cambridge, MA.

Wright, M., Robbie, K. and Ennew, C. (1997), "Venture capitalists and serial entrepreneurs”, Journal of Business Venturing, Vol. 12 No. 3, pp. 227-249. 


\section{LIST OF TABLES}

Table 1. Entrepreneurial (re)entry: Descriptive statistics

\begin{tabular}{|c|c|c|c|c|}
\hline & Entrepreneurs & Non-entrepreneurs & Overall & $\begin{array}{l}\text { Kruskal Wallis } \\
\text { (chi2) }\end{array}$ \\
\hline Gender (1 for male) & $\begin{array}{c}0.6382 \\
(0.4815)\end{array}$ & $\begin{array}{c}0.4891 \\
(0.5000)\end{array}$ & $\begin{array}{c}0.5076 \\
(0.5001)\end{array}$ & $19.169 * * *$ \\
\hline Entrepreneurs’ age (years) & $\begin{array}{l}46.3374 \\
(9.9507)\end{array}$ & $\begin{array}{c}43.5535 \\
(12.3698)\end{array}$ & $\begin{array}{c}43.8987 \\
(12.1287)\end{array}$ & $8.269 * * *$ \\
\hline Basic education & $\begin{array}{c}0.4268 \\
(0.4956)\end{array}$ & $\begin{array}{c}0.4517 \\
(0.4978)\end{array}$ & $\begin{array}{c}0.4486 \\
(0.4975)\end{array}$ & 0.537 \\
\hline Secondary studies & $\begin{array}{c}0.0976 \\
(0.2973)\end{array}$ & $\begin{array}{c}0.1070 \\
(0.3092)\end{array}$ & $\begin{array}{c}0.1058 \\
(0.3077)\end{array}$ & 0.203 \\
\hline Post-secondary studies & $\begin{array}{c}0.4756 \\
(0.5004)\end{array}$ & $\begin{array}{c}0.4413 \\
(0.4967)\end{array}$ & $\begin{array}{c}0.4456 \\
(0.4972)\end{array}$ & 1.026 \\
\hline Past entrepreneur & $\begin{array}{c}0.2561 \\
(0.4374)\end{array}$ & $\begin{array}{c}0.1824 \\
(0.3863)\end{array}$ & $\begin{array}{c}0.1915 \\
(0.3936)\end{array}$ & $7.556 * * *$ \\
\hline $\begin{array}{l}\text { Past entrepreneur - Positive } \\
\text { experience }\end{array}$ & $\begin{array}{c}0.1992 \\
(0.4002)\end{array}$ & $\begin{array}{c}0.1237 \\
(0.3293)\end{array}$ & $\begin{array}{c}0.1331 \\
(0.3397)\end{array}$ & $10.638 * * *$ \\
\hline $\begin{array}{l}\text { Past entrepreneur - Negative } \\
\text { experience }\end{array}$ & $\begin{array}{c}0.0569 \\
(0.2321)\end{array}$ & $\begin{array}{c}0.0587 \\
(0.2351)\end{array}$ & $\begin{array}{c}0.0585 \\
(0.2347)\end{array}$ & 0.012 \\
\hline Observations & 246 & 1,738 & 1,984 & \\
\hline
\end{tabular}

Standard deviation is presented in brackets. ${ }^{*}, * *, * * *$ indicates significance at the $10 \%, 5 \%$, and $1 \%$, respectively (Kruskal Wallis test).

Table 2. The effect of past entrepreneurial experience on innovativeness: Descriptive statistics

\begin{tabular}{|l|c|c|c|c|}
\hline & Mean & Std. dev. & Min & Max \\
\hline Gender (1 for male) & 0.6382 & 0.4815 & 0 & 1 \\
\hline Entrepreneur's age (years) & 46.3374 & 9.9507 & 27 & 64 \\
\hline Basic education & 0.4268 & 0.4956 & 0 & 1 \\
\hline Secondary studies & 0.0976 & 0.2973 & 0 & 1 \\
\hline Post-secondary studies & 0.4756 & 0.5004 & 0 & 1 \\
\hline Past entrepreneur & 0.2561 & 0.4374 & 0 & 1 \\
\hline $\begin{array}{l}\text { Past entrepreneur - Positive } \\
\text { experience }\end{array}$ & 0.1992 & 0.4002 & 0 & 1 \\
\hline $\begin{array}{l}\text { Past entrepreneur - Negative } \\
\text { experience }\end{array}$ & 0.0569 & 0.2321 & 0 & 1 \\
\hline Business age & 13.6789 & 10.9708 & 1 & 54 \\
\hline Extractive sectors & 0.1017 & 0.3028 & 0 & 1 \\
\hline Manufacturing sectors & 0.3130 & 0.4647 & 0 & 1 \\
\hline Business services sectors & 0.2276 & 0.4202 & 0 & 1 \\
\hline Consumer services sectors & 0.3577 & 0.4803 & 0 & 1 \\
\hline
\end{tabular}

Sample size: 246 business owners 
Table 3. Heckman model: The relationship between past entrepreneurial experience, current business ownership and reported innovativeness

\begin{tabular}{|c|c|c|c|c|c|c|}
\hline & \multicolumn{3}{|c|}{ 1) Serial entrepreneurship } & \multicolumn{3}{|c|}{ 2) Distinguishing the type of entrepreneurial experience } \\
\hline Past entrepreneur & $0.1553(0.0903)^{*}$ & $0.0308^{*}$ & $0.4232(0.1044)^{* *}$ & & & \\
\hline $\begin{array}{l}\text { Past entrepreneur: } \\
\text { negative experience }\end{array}$ & & & & $-0.0175(0.1626)$ & -0.0035 & $0.3919(0.2219)^{*}$ \\
\hline Gender ( 1 for male) & $0.3435(0.0755)^{* * *}$ & $0.0681 * * *$ & $0.0142(0.1111)$ & $0.3437(0.0756)^{* * *}$ & $0.0681 * * *$ & $0.0121(0.1111)$ \\
\hline Secondary studies & $-0.0702(0.1278)$ & -0.0139 & $-0.0816(0.1341)$ & $-0.0678(0.1278)$ & -0.0134 & $-0.0805(0.1345)$ \\
\hline ln business age & & & $0.0668(0.0559)$ & & & $0.0670(0.0561)$ \\
\hline Manufacturing & & & $0.0118(0.1030)$ & & & $0.0125(0.1028)$ \\
\hline Business services & & & $0.1147(0.0553)^{* *}$ & & & $0.1144(0.0534)^{* *}$ \\
\hline Consumer services & & & $0.2086(0.1492)$ & & & $0.2097(0.1492)$ \\
\hline $\begin{array}{l}\text { Inverse Mills ratio } \\
\text { (lambda) }\end{array}$ & & & $-0.0305(0.0140)^{* * *}$ & & & $-0.0360(0.0139)^{* * *}$ \\
\hline Log likelihood & & & -988.98 & & & -986.01 \\
\hline \multicolumn{7}{|l|}{ Selection equation } \\
\hline Wald test (chi2) & $53.12 * * *$ & & & $54.35 * * *$ & & \\
\hline Pseudo R2 & 0.0309 & & & 0.0322 & & \\
\hline Log likelihood & -720.60 & & & -719.64 & & \\
\hline \multicolumn{7}{|l|}{ Output equation } \\
\hline F-test & & & $2.87 * * *$ & & & $2.58 * * *$ \\
\hline Adjusted R2 & & & 0.0855 & & & 0.0893 \\
\hline VIF (min-max) & $1.08(1.01-1.14)$ & & $1.80(1.10-3.02)$ & 1.07 (1.01-1.14) & & $1.74(1.06-3.03)$ \\
\hline Observations & 1984 & & 246 & 1984 & & 246 \\
\hline
\end{tabular}

AME $=$ Average marginal effect. Robust standard error is presented in the brackets. ${ }^{*}, * *, * * *$ indicates significance at $10 \%, 5 \%$ and $1 \%$ respectively. 
APPENDIX

Table A1. Correlation matrix: The decision to become an entrepreneur

\begin{tabular}{|l|l|l|l|l|l|l|l|l|l|l|}
\hline & & 1 & 2 & 3 & 4 & 5 & 6 & 7 & 8 & 9 \\
\hline 1 & Business owner & 1.00 & & & & & & & \\
\hline 2 & Gender (1 for male) & $0.10^{* * *}$ & 1.00 & & & & & & \\
\hline 3 & Entrepreneur's age & $0.08^{* * *}$ & $-0.09^{* * *}$ & 1.00 & & & & & \\
\hline 4 & Basic education & -0.02 & $-0.07^{* * *}$ & $0.21^{* * *}$ & 1.00 & & & & \\
\hline 5 & Secondary studies & -0.01 & 0.03 & $-0.12^{* * *}$ & $-0.31^{* * *}$ & 1.00 & & & \\
\hline 6 & $\begin{array}{l}\text { Post secondary } \\
\text { studies }\end{array}$ & 0.02 & $0.05^{* *}$ & $-0.14^{* * *}$ & $-0.81^{* * *}$ & $-0.31^{* * *}$ & 1.00 & & \\
\hline 7 & Past entrepreneur & $0.06^{* * *}$ & 0.03 & $0.18^{* * *}$ & 0.01 & -0.01 & -0.01 & 1.00 & \\
\hline 8 & $\begin{array}{l}\text { Positive past } \\
\text { entrepreneurial } \\
\text { experience }\end{array}$ & $0.07^{* * *}$ & 0.02 & $0.16^{* * *}$ & 0.00 & -0.01 & 0.00 & $0.80^{* * *}$ & 1.00 \\
\hline 9 & $\begin{array}{l}\text { Negative past } \\
\text { entrepreneurial } \\
\text { experience }\end{array}$ & -0.01 & 0.03 & $0.06^{* * *}$ & 0.02 & 0.01 & -0.02 & $0.51^{* * *}$ & $-0.10^{* * *}$ & 1.00 \\
\hline
\end{tabular}

$*, * *, * * *$ indicates significance at $10 \%, 5 \%$ and $1 \%$ respectively. 
Table A2. Correlation matrix: Past entrepreneurial experience and reported innovativeness

\begin{tabular}{|c|c|c|c|c|c|c|c|c|c|c|c|c|c|c|}
\hline & & 1 & 2 & 3 & 4 & 5 & 6 & 7 & 8 & 9 & 10 & 11 & 12 & 13 \\
\hline 1 & Innovativeness & 1.00 & & & & & & & & & & & & \\
\hline 2 & Gender (1 for male) & 0.01 & 1.00 & & & & & & & & & & & \\
\hline 3 & Entrepreneur's age & -0.08 & $-0.09^{* * *}$ & 1.00 & & & & & & & & & & \\
\hline 4 & Basic education & -0.03 & $-0.07^{* * *}$ & $0.21^{* * *}$ & 1.00 & & & & & & & & & \\
\hline 5 & Secondary studies & -0.01 & 0.03 & $-0.12^{* * *}$ & $-0.31^{* * *}$ & 1.00 & & & & & & & & \\
\hline 6 & $\begin{array}{l}\text { Post secondary } \\
\text { studies }\end{array}$ & 0.04 & $0.05^{* *}$ & $-0.14^{* * *}$ & $-0.81^{* * *}$ & $-0.31^{* * *}$ & 1.00 & & & & & & & \\
\hline 7 & Past entrepreneur & $0.22^{* * *}$ & 0.03 & $0.18^{* * *}$ & 0.01 & -0.01 & -0.01 & 1.00 & & & & & & \\
\hline 8 & $\begin{array}{l}\text { Positive past } \\
\text { entrepreneurial } \\
\text { experience }\end{array}$ & $0.17^{* * *}$ & 0.02 & $0.16^{* * *}$ & 0.00 & -0.01 & 0.00 & $0.80^{* * *}$ & 1.00 & & & & & \\
\hline 9 & $\begin{array}{l}\text { Negative past } \\
\text { entrepreneurial } \\
\text { experience }\end{array}$ & $0.13^{* *}$ & 0.03 & $0.06^{* * *}$ & 0.02 & 0.01 & -0.02 & $0.51^{* * *}$ & $-0.10^{* * *}$ & 1.00 & & & & \\
\hline 10 & Business age & -0.05 & 0.08 & $0.51^{* * *}$ & $0.12^{*}$ & 0.09 & $-0.17^{* * *}$ & $-0.13^{* *}$ & -0.06 & $-0.14^{* *}$ & 1.00 & & & \\
\hline 11 & Extractive & -0.06 & 0.09 & 0.06 & 0.06 & 0.07 & $-0.10^{*}$ & $-0.14^{* *}$ & -0.10 & -0.08 & 0.09 & 1.00 & & \\
\hline 12 & Manufacturing & 0.04 & $0.31^{* * *}$ & -0.07 & $0.14^{* *}$ & -0.02 & $-0.13^{* *}$ & 0.03 & 0.06 & -0.05 & 0.08 & $-0.23^{* * *}$ & 1.00 & \\
\hline 13 & Business services & $0.05^{*}$ & $-0.20^{* * *}$ & 0.01 & $-0.23^{* * *}$ & -0.05 & $0.26^{* * *}$ & $0.15^{* *}$ & 0.09 & $0.12^{*}$ & $-0.15^{* *}$ & $-0.18^{* * *}$ & $-0.37^{* * *}$ & 1.00 \\
\hline 14 & Consumer services & 0.13 & $-0.18^{* * *}$ & 0.02 & 0.02 & 0.01 & -0.03 & -0.07 & -0.07 & 0.00 & 0.00 & $-0.25^{* * *}$ & $-0.50^{* * *}$ & $-0.41^{* * *}$ \\
\hline
\end{tabular}

$*, * *, * * *$ indicates significance at $10 \%, 5 \%$ and $1 \%$ respectively. 
Table A3. The effect of past entrepreneurial experience on reported innovativeness

\begin{tabular}{|l|c|c|}
\hline & \multicolumn{2}{|c|}{ Innovativeness (OLS models) } \\
\hline & \multicolumn{1}{|c|}{ Model 1 } & Model 2 \\
\hline Past entrepreneur & $0.4270(0.1065)^{* * *}$ & $0.4375(0.1185)^{* * *}$ \\
\hline Past entrepreneur: positive experience & & $0.3914(0.2268)^{*}$ \\
\hline Past entrepreneur: negative experience & & $0.0222(0.1151)$ \\
\hline Gender (1 for male) & $0.0227(0.1150)$ & $-0.4770(0.2169)^{* *}$ \\
\hline ln entrepreneur's age & $-0.4688(0.2167)^{* *}$ & $-0.1099(0.0455)^{* *}$ \\
\hline Basic education & $-0.1092(0.0486)^{* *}$ & $-0.0824(0.1377)$ \\
\hline Secondary studies & $-0.0833(0.1371)$ & $0.0670(0.0574)$ \\
\hline ln business age & $0.0668(0.0571)$ & $0.0124(0.1052)$ \\
\hline Manufacturing sectors & $0.0118(0.1051)$ & $0.1171(0.0534)^{* *}$ \\
\hline Business services sectors & $0.1170(0.0553)^{* *}$ & $0.2097(0.1526)$ \\
\hline Consumer services sectors & $0.2087(0.1523)$ & $1.5829(0.7445)^{* *}$ \\
\hline Intercept & $1.5528(0.7109)^{* *}$ & $2.88 * * *$ \\
\hline F-test & $3.18^{* * *}$ & 0.0827 \\
\hline Adjusted R2 & 0.0825 & 0.7370 \\
\hline Root MSE & 0.7355 & 246 \\
\hline Observations & 246 & $10 \%, 5 \%$ \\
\hline
\end{tabular}

Robust standard error is presented in the brackets. ${ }^{*}, * *, * * *$ indicates significance at $10 \%, 5 \%$ and $1 \%$ respectively. 